\title{
Cuban Agriculture Before 1959: The Social Situation'1
}

José Alvarez ${ }^{2}$

On October 28, 2000, U.S. President Bill Clinton signed the Trade Sanctions Reform and Export Enhancement Act (TSRA) which allowed U.S. firms to sell food and agricultural products to Cuba and other countries. However, the Cuban government did not purchase any of these products until December of 2001 following the devastating damage caused by Hurricane Michelle to important agricultural areas in November of that year.

Cuban purchases from U.S. firms amounted to $\$ 4.319$ million in 2001, \$138.635 million in 2002, and $\$ 256.9$ million in 2003. Cuba became the 35th most important food and agricultural export market for the United States in 2003, up from last (226th) in 2000. Actual purchases and pending contracts in the first-half of 2004 are at a pace to move Cuba into the top 20 most important markets of U.S. food and agricultural exports. Furthermore, because current U.S. legislation requires that all Cuban purchases from the United States must be conducted on a cash basis, the lack of credit risk associated with these sales makes Cuba one of the most attractive export markets for U.S. firms.

Anticipating changes in U.S.-Cuba trade relations, the Food and Resource Economics
Department at UF/IFAS initiated a research initiative on Cuba in 1990, including a 1993 collaborative agreement with the University of Havana, which has lasted to this day. (Most of the resulting publications can be found at http://www.cubanag.ifas.ufl.edu). We reiterate that our role as investigators is to provide the best available information and analyses from which rational decisions can be made. The reports included in this series intend to address the increasing level of interest in the Cuban market for food and agricultural products among U.S. firms and to assist them in becoming more familiar with that market. The complete list of documents in this series can be found by conducting a topical search for "Cuba" at http://edis.ifas.ufl.edu, or under

"Additional Information" at the end of this fact sheet.

\section{Introduction}

Very few studies of social indicators were carried out in Cuba before 1959. The two most complete included the 1946 National Agricultural Census (Memoria, 1951) and the 1953 Population, Housing, and Electoral Census (Oficina, 1954-55). In 1956-1957, the University Catholic Association (Agrupación Católica Universitaria, ACU) conducted a national survey (Gastón et al., 1957; the

1. This is EDIS document FE480, a publication of the Department of Food and Resource Economics, Florida Cooperative Extension Service, UF/IFAS, University of Florida, Gainesville, FL. Published July 2004. Please visit the EDIS website at http://edis.ifas.ufl.edu.

The author would like to thank the University Press of Florida (http://www.upf.com) for permission to reproduce material from the book Cuba's Agricultural Sector (Alvarez, 2004).

2. José Alvarez, Professor, Department of Food and Resource Economics, Everglades Research and Education Center, Belle Glade, FL, Florida Cooperative Extension Service, UF/IFAS, University of Florida, Gainesville, FL.

The Institute of Food and Agricultural Sciences is an equal opportunity/affirmative action employer authorized to provide research, educational information and other services only to individuals and institutions that function without regard to race, color, sex, age, handicap, or national origin. For information on obtaining other extension publications, contact your county Cooperative Extension Service office. Florida Cooperative Extension Service/Institute of Food and Agricultural Sciences/University of Florida/Christine Taylor Waddill, Dean. 
original Spanish version can found at http://edis.ifas.ufl.edu/FE292 and the English translation at http://edis.ifas.ufl.edu/FE297) that, despite the existing critiques discussed below, seemed to confirm the findings of the two censuses. Jolliffe et al. (1958) is perhaps the most quoted study on pre-1959 research on nutrition but, as explained below, it refers to a narrow universe. Díaz-Briquets $(1983 ; 1986)$ contain useful information on several of the variables discussed in this fact sheet.

In general, the first three studies are used most of the time. To balance the discussion with opposite points of view, other authors are also cited when they present sound critiques. The discussion starts with an assessment of the negative points in the Jolliffe study and the criticisms made to the ACU study.

\section{Critiques to the Jolliffe et al. Study}

Jolliffe et al. (1958) completed what has been considered a thorough treatment of the subject from January 16 to February 8, 1956 (less than a month). It is interesting to point out that the ACU survey started on November 30, 1956, and lasted approximately 10 months.

The findings by Jolliffe et al. seem to confirm and contradict some of the results in the ACU study. It is important to remember that this study was only concerned with nutritional aspects (although other social variables derive from that one) and thus did not cover the wider spectrum presented in the ACU study. In addition, a careful examination of the Jolliffe study reveals that:

- The study was composed of students in the sixth grade (included children ages 11 to 13 years attending public school and other pupils in sixth grade irrespective of age). Since a considerable number of children did not start school until after age six, about $80 \%$ of the sixth graders were 11 to 13 years old and $20 \%$ were older than 13.

- Entire classes or schools were selected up to the numbers needed to comprise about $5 \%$ of the sixth grade population in each of the six provinces of Cuba, but they varied from $4.8 \%$ in Camagüey province to $5.3 \%$ in Havana province. It is obvious that the latter province (with a higher percentage) had more inhabitants and better-fed students than the other provinces.

- The rural areas were selected "by chance" but the method is not explained.

- Urban areas were represented by the six provincial capital cities. These cities may have had a larger percentage of better-fed pupils than the smaller cities of the interior.

- The six urban areas (capitals) were compared with 12 rural areas, the latter also including small towns of the interior.

- Private school pupils were examined only in the city of Havana. The 163 students selected represented $2.73 \%$ of the sixth grade private school registration of Cuba. This method, however, may have selected a larger number of better-fed students.

The obvious conclusion is that the Jolliffe study, in addition to considering only nutrition and only sixth graders and thus cannot be compared with the rural workers studied in the ACU survey, has a number of flaws. But, as is the case with the ACU study, it cannot be totally rejected since it contains what some scholars consider benchmark figures.

\section{Critiques to the ACU Study}

The ACU study has been criticized for a number of reasons. Gordon (1983) appears to have outlined most of them. They include:

- It does not describe how the interviewees were selected or how the interviews were allocated to the political and geographic districts of the country.

- All nutritional and health data appear to be subjective data because of the way these questions were presented; measurements or laboratory investigations were not conducted.

(On pages 9 and 10, the ACU study describes the design of the questionnaire, what was done to avoid subjective responses, and the pretesting of the questionnaire. The second criticism appears to be true.) 
- It did not record sugar consumption, an important part of the rural worker's diet.

- It is unclear from their report whether food consumption and their frequency data are given in terms of percent of individuals who consumed a specific food or in terms of number of days per month during which the particular food was consumed, or both.

One final point should be made. The statistics in the ACU study relate to agricultural workers and not to the general rural population. Many authors on the island, despite the fact that the ACU study has been published there in several sources, are confused with what constituted the sample in the survey. The original publication states very clearly that the target population was the agricultural working family, defined as the family whose main source of income was a salary, wage, or in-kind retribution from the work performed for a third party who owned or managed land and agricultural machinery and tools (Gastón et al., 1957, pp. 11-12). This author has talked with a few of the persons who participated in the design of the questionnaire or in the interviews and they have confirmed that definition. Therefore, the results of the ACU study portray the situation of rural workers only and not that of the general population in the countryside although rural workers were the majority of that population.

With these caveats and comments, a number of social variables, as indicative of the status in Cuba's countryside on the eve of the revolution, are presented below.

\section{Income and Employment}

The 1946 Cuban agricultural census showed great disparities in family income distribution by farm size. There were 62,500 families with land holdings from 1 to 10 hectares and a monthly income of 37.54 pesos. The 147,189 families with holdings from 10 to 100 hectares averaged 69.86 pesos per month in income. The group with farm holdings above 1,000 hectares contained only 894 families with an average monthly income of 3,313.69 pesos (Valdés Paz, p. 32). It is obvious that the status of agricultural workers was not any better. As a matter of fact, according to the ACU study, the average monthly income of agricultural workers in 1956-1957 was 45.72 pesos (Gastón et al., 1957, p. 60).

The 1946 Census also quantified the average monthly salary of agricultural wage earners by type of land tenure. The highest salary (59.53 pesos) was earned by sub-renters and the lowest salary (33.90 pesos) was earned by sharecroppers (Valdés García, 1990, p. 28). The ACU study confirmed the census findings by estimating the annual income of a six-person peasant family at $\$ 548.75$, or $\$ 46.72$ per month. That level of income, however, was not achieved by $50 \%$ of the families of agricultural workers (p. 60). The same study calculated that the agricultural workers' population represented $34 \%$ of Cuba's total population, but received only $10 \%$ of the national income regardless of the method of payment (Gastón et al., 1957, p. 7).

Another characteristic of income disparities was its unequal distribution between urban and rural areas. According to Díaz-Briquets (1983), one of the most important changes brought about by the 1959 revolution was "the countrywide income redistribution, which reduced the great disparity in living conditions that had previously existed between the cities and rural areas" (p. 125).

The employment situation was no better than the income conditions. Out of 830,000 agricultural workers in 1946, more than half were seasonal workers. In the case of wage earners, for example, the number of seasonal workers was almost eight times higher than that of workers with permanent employment (Valdés García, 1990, p. 26).

Data for 1953 show that agriculture was Cuba's largest employer, followed by industry, commerce, and services (Zuaznábar, 1986, p. 12). The agricultural sector employed $47.4 \%$ and $5.8 \%$ of the male and female workers, respectively. According to census data, 818,700 workers were employed in agriculture in 1953, which increased to 855,000 workers in 1957 (Wylie, 1969, p. 6).

Wylie also states that, prior to 1959 , the supply of agricultural labor was adequate for the level of output and, in fact, workers were underemployed during the so-called tiempo muerto ("dead" season) which took place between sugarcane harvests. Given 
the agricultural nature of most of the employment and the seasonality of most crops, it is not surprising that there were high levels of unemployment and underemployment in the agricultural labor force. This situation, along with the low income earned by agricultural workers, contributed to the social injustices described below.

\section{Education}

The most recent data on education before 1959 are those from the 1953 Population, Housing, and Electoral Census. Although 36.5\% of the total Cuban population lived in rural areas, slightly more than $77 \%$ of those between 5 and 24 years of age did not attend school. About $70 \%$ of the children and young people in the countryside between 5 and 18 years of age did not attend classes, rising to almost $82 \%$ for those in the age bracket between 11 and 24 years. One logical explanation is that rural poverty forced children and young people to start working at an early age to help support their families.

Of the 1.5 million inhabitants who had not completed a single year of school, $67 \%$ lived in rural areas. Of the 86,000 who had reached middle school, only $4.7 \%$ lived in the countryside. Of the 88,000 citizens who had reached high school, only $4.3 \%$ were rural inhabitants. In terms of university education, only $2.4 \%$ of the 1,292 who had managed to go to a university resided in rural areas. The 1953 Census revealed an inverse relationship between the degree of schooling and rural participation.

The 1953 Census also found a very high degree of illiteracy among the general population and the rural population in particular. For example, $23.6 \%$ of Cubans older than 10 years were illiterate and $41.7 \%$ of those lived in the countryside. Illiteracy was more frequent among older adults. Although that finding reflected that positive steps were being taken with the younger generations, the efforts were still not enough, given the magnitude of the problem. In 1956-1957, the ACU study found that $43 \%$ of rural workers were illiterate and that $44 \%$ of them had never attended school. The degree of illiteracy and low level of education conspired against any rural development efforts.
During the 1958-1959 school year, there were 7,567 schools in Cuba, employing 17,355 persons. That gives a ratio of 2.3 employees per school. There were teachers in both urban and rural areas in charge of four or five grades of students in the same classroom, sometimes teaching only half sessions. That was true for many but not all schools, both public and private.

\section{Housing}

Housing, including water supply and electricity, was not any better than employment, income, and education for the rural population. The 1953 Population, Housing, and Electoral Census provides useful data from which to draw some conclusions about the state of rural housing at that time. Almost $47 \%$ of the total number of dwellings nationwide was classified as either in ruinous or bad shape (30\% urban and $75 \%$ rural), houing $53 \%$ of the Cuban population at the time of the 1953 Census. Another $40.4 \%$ of the total number of dwellings were considered as either in moderate or acceptable shape (50\% urban and $24.4 \%$ rural), housing $37 \%$ of the Cuban population. Only $13 \%$ of the total number of dwellings were classified as in good shape (20\% urban and $0.6 \%$ rural), housing only $10 \%$ of the Cuban population.

As in the previous cases, the differences between the urban and rural areas were so sharp as to make it difficult to go unnoticed. When studying changes in Cuba's housing conditions with data from the 1899 and 1953 Censuses, Díaz-Briquets (1983, pp. 41, 44) states that, despite different definitions given to urban areas by the two censuses, the percentages of the different variables measuring housing conditions improved for the country as a whole, particularly in the urban areas because of the increase in urbanization.

A couple of obvious observations are worth mentioning: (1) the situation in the countryside was the result of the unprofitability of housing construction by private companies and non-interest by the government in building affordable housing for the rural population, and (2) the housing market was a highly speculative one in urban areas and almost nonexistent in rural areas where most of the farmers 
and rural workers built their own dwellings with poor quality materials.

The most common housing in the countryside was what Cubans call bohio, an Indian word used to describe the type of dwelling found by Christopher Columbus when he discovered Cuba in 1492. It is built, with the help of family and neighbors, with wood, yaguas (the lower parts of the branches from the palm trees), and yarey (leaves from the palm trees). Most of this type of housing had dirt floors although some farmers could afford cement. Sanitary facilities, generally a privy, located almost always a few meters from the house, were built with the same materials. According to Díaz-Briquets, from 1899 to 1953, "the percentage of urban dwellings with toilet facilities increased greatly, and significantly more in the Havana area than elsewhere. The relative distribution of waste-disposal facilities in the rural areas of the country changed only slightly" (1983, p. 41) and "the situation in rural Cuba in 1953 was still primitive" (p. 44). The 1953 Census also found that only $7 \%$ of the houses had either indoor or outdoor toilets for individual or collective use, with $34 \%$ of the outdoor privies in the countryside. Almost $87 \%$ of dwellings lacking these facilities were in rural areas. Very similar figures were found by ACU's study in 1956-1957.

Water supply was available from different sources and distributed by different means: internal aqueducts, internal cisterns, external water supply lines, rivers, wells, or springs. Díaz-Briquets' findings reveal that from 1899 to 1953 , water supply conditions in rural areas deteriorated despite a remarkable improvement in urban areas. The evidence suggests that, "over the fifty-year span the improvements in housing were concentrated exclusively in urban areas" (1983, p. 41). The 1953 Census found that $2.4 \%$ of the national total number of dwellings in rural areas obtained their water through internal aqueducts; $3.4 \%$ through internal cisterns; $17.9 \%$ through external water supply lines; and $73.4 \%$ obtained water from rivers, wells, or springs. A few years later, ACU's study found that about $64 \%$ of rural dwellings had neither toilets nor privies. Of those having toilets and privies, $7.6 \%$ of the toilets were outside the house, $2 \%$ of the toilets were inside the house, and $25 \%$ of the privies were located outside the house.

Concerning electricity, only $5.8 \%$ of the housing that received that service at the national level was found in rural areas. Of those using acetylene or kerosene for lighting and household use, $78.8 \%$ and $80.8 \%$, respectively, were located in the countryside.

\section{Nutrition and Health}

These are perhaps the two variables where most of the controversy has developed. Food consumption statistics in the ACU's study serve as a good starting point for an analysis of nutrition and health in Cuba's countryside and also to introduce opposite points of view.

The first issue involves daily caloric intake. Based on self-reported (not measured directly) average weight-to-height information (later confirmed by Gordon using more modern techniques) on agricultural workers and the nature of their work, the ACU study set the minimum number of required daily caloric intake at 3,500 calories. Their results showed that most of the rural workers had a deficit of 1,000 calories at the time they were working. Gordon $(1983$, p. 8) states that, in order to have a gross estimate of the caloric intake of the population, it is necessary to obtain accurate data on the actual kinds and quantities of all food products consumed during a period of time not less than 24 hours, as done in the ACU study, which did not include sugar consumption. Gordon believes that the 2,500 calories must have been below the true caloric intake, so they should have said "at least of 2,500 calories." (For comparison purposes, the FAO set the country's average calories per person, per day for 1958 at 2,682.) The ACU reported an index of malnutrition of $91 \%$, which is questioned by Gordon $(1983$, p. 8). Benjamin et al. (1986, pp. 95, 203) provide a description of the methodological flaws, leading them to consider the $91 \%$ index an inflated figure, but they also recognize that it nevertheless conveys the magnitude of rural malnutrition.

It is obvious that the figures related to diet cannot apply to farmers and peasants (who did not work for others) since they usually had conucos (small land parcels to grow food for 
self-consumption) and raised small animals such as chickens and pigs for the same purpose.

The lack of a sufficient diet and sound sanitary conditions brought about a series of diseases that, which were very difficult to eradicate because of the scarcity of medical assistance in rural areas. ACU's study mentioned that $14 \%$ of the participants suffered, or had suffered, from tuberculosis and 13\% from typhus. In addition, $36 \%$ of rural workers in the sample had parasites and another $31 \%$ had malaria (1957, pp. 26-27). Data compiled by Díaz-Briquets (1983, pp. 55-61) for several periods between 1901 and 1953 show impressive decreases in mortality rates over time. The problem is that all the data pertain to the city of Havana. No information was available for the cities of the interior, let alone for rural areas.

Public medical assistance was conspicuously absent in most of Cuba's countryside. The ACU study revealed that $80.7 \%$ of the survey respondents had received medical attention from a paid physician and only $8 \%$ had obtained medical services paid by the state. This reality was the result of the lack of resources allocated to medical care in the countryside despite the existence of one physician in active practice per every 1,000 persons in Cuba in 1957, as reported by the Pan American Union (1960).

Sometimes the main objective of analyzing nutrition and health data is to find the causes for changes in mortality and fertility rates. The performance of these two variables is believed to result in changes in average longevity and to be indicative of social and economic development. These are the facts from which the theory of demographic transition was formulated. Díaz-Briquets $(1983$; 1986) and McGuire and Frankel (2003) have conducted several studies to prove that theory to be true and positive for Cuba during the five decades preceding the 1959 revolution.

Since it is impossible to summarize these studies in a few lines, let us concentrate on the main variables: total and infant mortality rates, life expectancy, and fertility rate. From the 1901 Census to the 1953 Census, total death rates declined from 22.4 to 10.7 per 1,000 persons, per year, in the city of Havana (Díaz-Briquets, 1983, p. 173). Although specific infant mortality rates for comparison purposes are not available (the 1960 Statistical Abstract of the United States puts the figure per 1,000 persons at 5.8 in 1958), Díaz-Briquets states that "unsanitary conditions, inadequate diets, and infectious diseases are the main accomplices in high infant mortality in poor countries, and certainly took a toll among children of the more dispossessed pre-revolutionary peasantry" (1986, p. 39). Mortality declines, according to Díaz-Briquets (1983) "have almost always been followed by fertility declines" (p. 5), which, according to the theory of demographic transition, is indicative of socio-economic development. Life expectancy at birth increased from 37.2 years in 1901 to 62.7 years in 1953 in the city of Havana, and from 34.2 years in 1905 to 64.1 years in 1960 in Cuba (1983, pp. 19, 103).

\section{Two Important Developments in Pre-1959 Rural Cuba}

Most of the maladies described previously reflected a failure to implement and enforce existing legislation and, especially, the 1940 Cuban Constitution. There were, however, several pieces of legislation, as progressive as in the constitution, were put into practice with very positive results. Two examples are the Law of Sugar Coordination of 1937 (Gaceta, 1937, pp. 3-23) with its corresponding rules and regulations (Gaceta, 1938, pp. 24-158), and the legislation creating the Agricultural and Industrial Development Bank (Gaceta, 1950).

\section{The Law of Sugar Coordination of 1937}

This law defined the relationship between capital and labor in the sugar industry. The bill was signed into law on September 2, 1937. It consisted of seven chapters and 55 articles. Its importance was demonstrated by its objectives that, among others, intended to:

- protect the grower of independent cane (cane grown by a private entity for milling in someone else's mill), usually the smallest producers.

- guarantee a minimum quota, even at the expense of reducing that of growers of administration cane (cane grown by a person or 
corporation for milling in their own mill) under some circumstances.

- establish a method of payment for growers of independent cane, mainly based on a specific degree of polarization.

- provide a system for checking the accuracy of the reports concerning the weight and sucrose content of the sugarcane.

- regulate the moratorium of debts by growers of independent cane.

- establish the right of independent growers to remain on rented lands, and regulate the payment of leases.

- regulate the payment for harvesting, loading, and transporting the sugarcane to the mill in addition to activities related to the production and handling of sugar.

- establish base payments on sugar yields and prices.

- establish a minimum wage (to be paid bi-weekly) based on the price of sugar.

- encourage the development of labor contracts between the labor unions and the mill owners.

- enumerate the penalties and sanctions to which mill owners were subject for not following the law.

- establish the important Arbitrage Commission.

- force mill owners to donate land for the creation of cooperatives by workers and employees, and for the growing of fruits and vegetables for their subsistence.

The set of rules developed for the Law of Sugar Coordination was contained in Decree No. 319 of February 16, 1938. There were 205 articles under eight chapters, devoted to the definition of terms and to the specific rules on how to enforce the law.

The Law of Sugar Coordination was a progressive piece of legislation. Recall that Cuba was subject to a system of sugar quotas emanating from its sugar trade with the United States. This law resulted in a just framework for all the main parties involved: the growers of independent cane, the growers of administration cane (mill owners), and the agricultural and industrial workers. Its importance for Cuba was clear, given the fact that sugarcane was the most important crop and sugar was the main export crop. It is no wonder that, despite normal cyclical conflicts between capital and labor, it is still praised by former growers, processors and workers.

\section{The Agricultural and Industrial Development Bank}

Law No. 5 created the Banco de Fomento Agrícola e Industrial de Cuba (BANFAIC), which was enacted on December 20, 1950, by President Carlos Prío Socarrás. (In fact, Law No. 13 of 1948, establishing Cuba's national bank, envisioned an agricultural bank as a necessary complement.) Law No. 15 of 1949 authorized the issuance of $\$ 200$ million in bonds. Of the $\$ 25$ million going to BANFAIC, an equal distribution went to the agricultural and industrial branches.

The governing organism was a board of five directors. At the lower levels, BANFAIC had an agricultural credit board and an industrial credit board. There were also three managers: one for agriculture, one for industry, and one for administration.

BANFAIC had two important features: (1) the establishment of personnel selection procedures based on test scores, and (2) a tenure system for all its personnel after successfully completing the first six months of employment. These two features were intended to isolate managers and employees from the swings of politics. Another important part was the hiring of technical personnel. It is interesting to note that the bank had more agronomists on its payroll than the Ministry of Agriculture.

Another important feature was the granting of credit for a variety of agricultural activities, including planting, growing, and harvesting; purchases of livestock for all purposes; chemical products and other inputs; storage; and transport of products. Credit for these activities was granted for 18 months or less. Credit also was granted for permanent crops, 
buildings, machinery, irrigation, and many other purposes. Credit for these was granted for five to 25 years. These credits were processed through the Rural Credit Associations (Asociaciones de Crédito Rural, ACR), created by the same law that established BANFAIC. Thirteen ACRs, with 20 offices throughout Cuba and more than 30,000 members, were functioning during the five or six years of their existence. On December 31, 1959, credit to be collected amounted to $\$ 36,554,474$.

\section{Conclusion}

The data have shown the existence of two pre-1959 Cubas: an urban Cuba, especially the city of Havana, and a rural Cuba. It is clearly stated in the ACU study: "The city of Havana is living an epoch of extraordinary prosperity, while in the countryside, people, especially the agricultural workers, are living in sluggish, miserable, and desperate conditions too difficult to believe" (Gastón et al., 1957, p. 6). Thus it is obvious that the living conditions in the city of Havana, and perhaps in a few other urban areas of Cuba, did not parallel those described in this fact sheet for the countryside.

However, this fact sheet is about Cuban agriculture. It is clear that viewing the aggregated statistics for Cuba as a whole does not give an accurate picture of the conditions among Cuba's rural population and agricultural workers. For example, Cuba's per capita income figures ignore the critical question of distribution of that income. Statistics on the value of imports per capita are deceiving because these imports went exclusively to urban areas with the necessary purchasing power. As we have seen previously, per capita caloric consumption data ignore the nutritional deficiencies experienced by Cuba's rural populace. Finally, statistics, such as per capita number of televisions, telephones, automobiles, hospitals, and schools, tend to mask the basic fact that much of rural Cuba at that time had no electrical or telephone service and that automobiles, hospitals, and schools were concentrated in the city of Havana and other urban areas.

Efforts to break down figures between urban and rural areas are hampered by the fact that separate statistics were not compiled. The work of
Díaz-Briquets $(1983 ; 1986)$ offers some insights, but it only relates to demographic variables and the emphasis is on post-1959 Cuba. Even when he breaks down his variables between urban and rural areas, the conclusion is always the same: there existed a substantial difference in favor of urban versus rural areas in all the variables studied.

Another category of studies utilizes the previous statistics to compute development indexes to compare Cuba with other developing countries. These variables, however, should be analyzed with absolute, not relative, figures to avoid overlooking the misery that clearly characterized Cuba's rural population at the time.

\section{References}

Alvarez, José. 2004. Cuba's Agricultural Sector. Gainesville, FL: University Press of Florida.

Benjamin, Medea, Joseph Collins, and Michael Scott. 1986. No Free Lunch-Food \& Revolution in Cuba Today. New York, NY: Grove Press.

Díaz-Briquets, Sergio. 1983. The Health Revolution in Cuba. Austin, TX: University of Texas Press.

Díaz-Briquets, Sergio. 1986. How to Figure Out Cuba—Development, Ideology, and Mortality. Caribbean Review 15 (2, Spring): 8-42.

Gaceta Oficial de la República de Cuba. Various Issues. La Habana.

Gastón, Melchor W., Oscar A. Echevarría, and René F. de la Huerta. 1957. ¿Por Qué Reforma Agraria? Serie-B, Apologética, Folleto No. 23, Buró de Información y Propaganda, Agrupación Católica Universitaria, La Habana, Cuba.

Gordon, Jr., Antonio M. 1983. The Nutriture of Cubans: Historical Perspective and Nutritional Analysis. Cuban Studies 13 (2, Summer): 1-34.

Jolliffe, Norman, Robert S. Goodhart, Morton Archer, Hady Lopez, and Flavio Galban Diaz. 1958. Nutrition Status Survey of the Sixth Grade School Population of Cuba. Journal of Nutrition 64 (3): 355-398. 
McGuire, James W., and Laura B. Frankel. 2003. Mortality Decline in Cuba, 1900-1959: Patterns, Comparisons, and Causes. Paper presented at the 2003 Meeting of the Latin American Studies

Association, Dallas, Texas (March 27-29).

Memoria del Censo Agrícola Nacional de 1946. 1951. La Habana: Ministerio de Agricultura de la República de Cuba.

Oficina Nacional de los Censos Demográfico y Electoral. 1954-55. Censo de Población, Electoral y de Vivienda. La Habana.

U.S. Bureau of the Census. 1960. Statistical Abstract of the United States. Washington, DC.

Valdés García, Orlando. 1990. La Socialización de la Tierra en Cuba. La Habana: Editorial de Ciencias Sociales.

Valdés Paz, Juan. 1997. Procesos Agropecuarios en Cuba, 1959-1995. La Habana: Eitorial de Ciencias Sociales.

Wylie, Kathryn H. 1969. A Survey of Agriculture in Cuba. ERS-Foreign 268, U.S. Department of Agriculture, Washington, DC, June.

Zuaznábar, Ismael. 1986. La Economía Cubana en la Década del 50. La Habana: Editorial de Ciencias Sociales.

\section{Additional Information}

Below is a list of the fact sheets in this series on Cuban Agriculture. They can be accessed by clicking on the highlighted links:

- FE479 - Cuban Agriculture Before 1959: The Political and Economic Situations

- FE480 - Cuban Agriculture Before 1959: The Social Situation

- FE481 - Transformations in Cuban Agriculture After 1959

- FE482 - Overview of Cuba's Food Rationing System
- FE483 - The Issue of Food Security in Cuba

- FE484 - Acopio: Cuba's State Procurement and Distribution Agency

- FE485 - Antecedents of the Cuban Agricultural Policies of the 1990s

- FE486 - Chronology of Cuban Reform Policies with Emphasis on Agriculture, 1993-1995

- FE487 - Cuba's Basic Units of Cooperative Production

- FE488 - Cuba's Agricultural Markets

- FE489 - Environmental Deterioration and Conservation in Cuban Agriculture

- FE490 - The Potential Correlation between Natural Disasters and Cuba's Agricultural Performance 